\title{
WYBRANE ASPEKTY PRZENIESIENIA POZWOLENIA WODNOPRAWNEGO
}

\author{
SELECTED ASPECTS \\ OF WATER PERMITS TRANSFER
}

\section{STRESZCZENIE}

Pozwolenie wodnoprawne stanowi istotny instrument administracji publicznej, który służy określeniu sposobów korzystania z zasobów wodnych, kontroli nad nimi oraz ich ochrony. Konkretne rozstrzygnięcia dotyczące pozwoleń wodnoprawnych ujęte zostały głównie w ustawie Prawo ochrony środowiska z 27 kwietnia 2001 r. oraz ustawie Prawo wodne z 18 lipca 2001 r.

Regulacje wprowadzone przez ustawę nowelizującą $\mathrm{z}$ dnia 11 lipca 2014 r. dokonują niezwykle istotnych zmian w zakresie pro-

* Doktorantka w Katedrze Ubezpieczeń Gospodarczych WPiA UMK.

** Doktorant w Katedrze Prawa Administracyjnego WPiA UMK. 
cedury przenoszenia pozwoleń wodnoprawnych dotyczących eksploatacji instalacji. Co prawda wprowadzony automatyzm sukcesji pozwoleń z jednej strony znacząco upraszcza całą procedurę, z drugiej jednak strony, z uwagi na niekompletność wprowadzonych zmian, stwarza szereg nowych problemów. Niniejsze opracowanie ma na celu przybliżenie instytucji pozwolenia wodnoprawnego ze szczególnym uwzględnieniem pozwoleń emisyjnych oraz przedstawienie problemów, które pojawiły się na gruncie nowej regulacji.

\section{Słowa kluczowe}

Prawo wodne; prawo ochrony środowiska; pozwolenie wodnoprawne; przeniesienie pozwolenia wodnoprawnego.

\section{ABSTRACT}

A permit required by Water Law Act is one of the important instruments of public authorities to specify the ways of water resources use, their control and protection. Specific decisions concerning water permits are mainly included in the Environmental Protection Act of 27 April 2001 and the Water Law Act of 18 July 2001.

The regulations implemented by the amending Act of 11 July 2014 introduce significant changes to the procedure of transferring water permits concerning the use of water systems. On the one hand, the automatic succession of water permits implemented by this Act significantly simplifies the whole procedure, but on the other hand, due to the incompleteness of these amendments, it creates a series of new problems. The article intends to bring closer the concept of water permits with particular emphasis on emission permits and to present problems that have arisen under new regulations.

\section{Keywords}

Water Law; Environment Law; permit required by Water Law Act (water permit); transfer of a water permit. 


\section{WPROWADZENIE}

Możliwość korzystania ze środowiska uzależniona jest niejednokrotnie od uzyskania odpowiedniej zgody ze strony właściwych organów administracji publicznej. Dotyczy to naturalnie również działań podejmowanych w kontekście dobra ogólnego, jakim są wody. Przejawem takiej reglamentacji jest bez wątpienia pozwolenie wodnoprawne ${ }^{1}$. Jednym z celów wprowadzonych ograniczeń jest dążenie do zrównoważenia interesu publicznego z interesami prywatnymi w taki sposób, aby osiągnięty kompromis pozwalał na jednoczesne sprawne $i$ harmonijne funkcjonowanie społeczeństwa z ochroną środowiska.

Pozwolenie wodnoprawne jest decyzją administracyjną wydawaną przede wszystkim w oparciu o przepisy ustawy prawo wodne ${ }^{2}$ oraz przepisy regulujące zagadnienie ochrony środowiska $^{3}$. Normy proceduralne $\mathrm{w}$ tym zakresie reguluje przede wszystkim kodeks postępowania administracyjnego ${ }^{4}$ oraz właściwe normy proceduralne zawarte we wspomnianych wyżej przepisach (ustawa prawo wodne, ustawa p.o.ś.). Pozwolenie wodnoprawne służy urzeczywistnianiu podstawowego celu ustawowego, jakim jest właściwa gospodarka wodami realizowana w myśl zasady zrównoważonego rozwoju oraz ochrona wód. Za pomocą instrumentu omawianej decyzji administracyjnej ustawa prawo wodne realizuje również normę konstytucyjną wyrażoną w art. 5 Konstytucji z dnia 2 kwietnia 1997 r. ${ }^{5}$, zgodnie z którą Rzeczpospolita Polska zapewnia ochronę śro-

1 Pozwolenie wodnoprawne do decyzji reglamentacyjnych zaliczył m.in. W. Radecki, Ochrona środowiska. Problemy społeczne ekonomiczne i prawne, Warszawa 2001, s. 270.

2 Ustawa z dnia 18 lipca 2001 r. Prawo wodne, tj. Dz. U. z 2012 r., poz. 145 ze zm., dalej: ustawa prawo wodne.

3 Ustawa z dnia 27 kwietnia 2001 r. Prawo ochrony środowiska, tj. Dz. U. z 2013 r., poz. 1232 ze zm., dalej: ustawa p.o.ś.

4 Ustawa z dnia 14 czerwca 1960 r. Kodeks postępowania administracyjnego, tj. Dz. U. z 2013 r., poz. 267 ze zm., dalej: kodeks postępowania administracyjnego.

5 Konstytucja Rzeczypospolitej Polskiej z dnia 2 kwietnia 1997 r., Dz. U. z 1997 r. Nr 78, poz. 483 ze zm. 
dowiska, kierując się zasadą zrównoważonego rozwoju. Przyjmuje się, że zrównoważony rozwój rozumiany jest jako „rozwój społeczno-ekonomiczny, zachowujący cechy trwałości w długim okresie i nieoddziałujący destruktywnie na środowisko, w którym zachodzi. Oznacza zaspokajanie potrzeb obecnego pokolenia bez pozbawiania przyszłych pokoleń możliwości zaspokojenia ich potrzeb"6.

Decyzja wodnoprawna stanowi zatem niezwykle ważny instrument służący ochronie środowiska i kształtowaniu polityki tej ochrony. Z punktu widzenia możliwości realizacji inwestycji (w tym uzyskania pozwolenia na budowę) jest ona również jednym z bardziej istotnych rozstrzygnięć administracyjnych. Często dochodzi do sytuacji, w której możliwość realizacji procesu inwestycyjnego uzależniona jest od wcześniejszego uzyskania pozwolenia wodnoprawnego. Stanowi ono wówczas niezbędny element warunkujący możliwość uzyskania pozwolenia na budowę ${ }^{7}$ Sama zasadność istnienia instytucji pozwolenia wodnoprawnego jako instrumentu ochrony interesu publicznego nie jest co do zasady kwestionowana. Funkcjonuje w obrocie prawnym zarówno pod rządami aktualnie obowiązującej ustawy, jak i ustawy wcześniejszej z dnia 24 października 1974 roku. Można skonstatować, że ustawodawca, tworząc odpowiednie przepisy prawa odnoszące się do zagadnienia wydawania pozwoleń wodnoprawnych, należycie zrównoważył interes publiczny z interesami prywatnymi. Konstrukcją prawną wspomagającą utrzymanie tej równowagi są przepisy umożliwiające przenoszenie pozwoleń wodnoprawnych na inny podmiot niż ich pierwotny adresat. Ustawa z dnia 11 lipca 2014 r. o zmianie ustawy - Prawo ochrony środowiska oraz niektórych innych ustaw $^{9}$ nowelizuje przepisy regulujące tę problematykę, poddając je istotnym zmianom. Nadal aktualne w swej treści pozo-

6 J. Kundera, W. Szmyt, Leksykon polityki regionalnej Unii Europejskiej, Kraków 2008, s. 93.

7 Art. 32 ust. 1 pkt 2 ustawy z dnia 7 lipca 1994 r. Prawo budowlane, Dz. U. z 2013 r. poz. 1409 ze zm.

8 Ustawa z dnia 24 października 1974 r. Prawo wodne, Dz. U. Nr 38, poz. 230 ze zm.

9 Dz. U. z 2014 r., poz. 1101. 
stają właściwe przepisy prawa wodnego (omówiony w dalszej części tekstu art. 134). W tym zakresie diametralne modyfikacje zachodzą $\mathrm{w}$ stosunku do odpowiednich postanowień ustawy p.o.ś. (uchylenie przepisów 190 i 191 statuujących o możliwości przeniesienia pozwolenia wodno prawnego w drodze uprzedniego uzyskania administracyjnej decyzji przenoszącej). W tym miejscu wstępnie nadmienić należy o liberalnym charakterze wprowadzonych zmian. Najnowsza uchwalona przez Sejm nowelizacja przepisów ustanawia automatyzm w zakresie sukcesji praw i obowiązków wynikających z tzw. emisyjnych pozwoleń wodnoprawnych (art. 189 znowelizowanej ustawy p.o.ś., który jest przedmiotem późniejszej analizy).

Tak istotne zmiany usuwają wątpliwości co do rzeczowego charakteru stosunku administracyjnoprawnego wynikającego z pozwolenia wodnoprawnego ${ }^{10}$.

Powyższa nowelizacja nie rozwiązuje jednak wszystkich problemów, które mogą pojawić się w konsekwencji uchwalenia nowych przepisów dotyczących zmiany adresata pozwolenia wodnoprawnego. Szczegółowo problematyka ta zostanie omówiona w dalszej części opracowania.

\section{CHARAKTER PRAWNY POZWOLENIA ADMINISTRACYJNEGO}

Przyjmowany jest pogląd, że instytucja prawna pozwolenia daje odpowiednie instrumenty kształtowania zachowań określonych podmiotów chcących uzyskać dane pozwolenie, tak aby pozostawały one zbieżne z interesem ogólnym, na straży którego stoi organ administracji publicznej. Modelowanie pożądanych postaw adresatów pozwoleń osiągane jest przez kształtowanie treści danego pozwolenia poprzez wprowadzanie określonych obowiązków, dat ich obowiązywania czy wskazy-

10 Zob. szerzej na temat charakteru prawnego pozwolenia wodnoprawnego E. Szczygłowska, Sukcesja uprawnień i obowiązków administracyjnych, Warszawa 2009, s. 169-182 oraz 218-222. 
wanie na sytuacje uzasadniające cofnięcie lub zmianę danego pozwolenia ${ }^{11}$.

Zgodnie z poglądem D. R. Kijowskiego „organ administracji publicznej, wydając pozwolenie, określa pozycję prawną indywidualnie oznaczonego podmiotu prawa znajdującego się w konkretnych okolicznościach"12. Podejmowanie działań bez wymaganego pozwolenia w sytuacji, gdy ustawodawca przewidział obowiązek jego uzyskania, powoduje, że dane działanie pozostaje niezgodne $\mathrm{z}$ prawem i powinno zostać zaniechane. Przyjąć można, że w danych okolicznościach faktycznych pozwolenie dokonuje konkretyzacji uprawnień i obowiązków adresata w oparciu o obowiązujące normy prawne wskazujące na przesłanki jego uzyskania ${ }^{13}$.

W czasie trwania procesu udzielania pozwolenia wodnoprawnego organ ma szansę na pozyskanie szeregu niezbędnych informacji i szczegółowych danych o planowanym przedsięwzięciu. Możliwość ta zostaje zwiększona poprzez zapewnienie udziału w postępowaniu podmiotom trzecim, zainteresowanym danym postępowaniem ze względu na swój interes prawny. Osoby te, z uwagi na często odmienne interesy prawne, są w stanie przedstawić nowe argumenty w sprawie i przewidzieć dalsze skutki ewentualnego wydania decyzji administracyjnej ${ }^{14}$.

Zapewnieniu realizacji ustawowych celów ochrony środowiska i należytej gospodarki wodnej oraz zaspokajaniu potrzeb ludności służyć mają przepisy dotyczące sytuacji, w których konieczne jest uzyskanie pozwolenia wodnoprawnego.

11 E. K. Czech, Rola pozwolenia na wprowadzenie gazów lub pyłów do powietrza $w$ działaniach administracji publicznej, [w:] E. K. Czech (red.), Uwarunkowania ochrony środowiska. Aspekty krajowe, unijne, międzynarodowe, Warszawa 2006, s. 73.

12 D. R. Kijowski, Pozwolenia $w$ administracji publicznej, Białystok 2000, s. 179.

13 Ibidem.

14 E. K. Czech, op. cit., s. 73-74. 


\section{WARUNKI DOPUSZCZALNOŚCI PRZENOSZENIA DECYZJI ADMINISTRACYJNYCH}

Z uwagi na osobisty charakter decyzji administracyjnej tradycyjna nauka prawa negowała możliwość sukcesji praw i obowiązków z niej płynących, określając ją jako niedopuszczalną ${ }^{15}$. Ogólna zasada takiej nieprzenoszalności wynika z odmiennych charakterów stosunków cywilnoprawnych i administracyjnoprawnych, w których te ostatnie mają przymiot bezwzględnie wiążących ${ }^{16}$. Tadeusz Woś wskazuje, że „moc wiążąca aktu administracyjnego rozciąga się tak daleko tzn. obejmuje tylko takie sytuacje, w których będziemy mieć do czynienia ze stosunkiem prawnym identycznym, jak stosunek skonkretyzowany w akcie"17. Należy w tym miejscu przypomnieć, że elementami stosunku administracyjnego niezmiennie pozostają: podmiot, przedmiot oraz treść ${ }^{18}$. W prawie administracyjnym bez wyraźnego upoważnienia normatywnego nie ma miejsca na zmianę elementu podmiotowego, jakim jest adresat decyzji ${ }^{19}$. Jeśli jednak zmiana taka nastąpiłaby, wówczas dany akt administracyjny powinien zakończyć swój byt prawny, gdyż przestałby być tożsamy w swych elementach ze stosunkiem pierwotnym - a co za tym idzie - spełniłby się warunek ustania stosunku prawnoadministracyjnego.

Dynamicznie zachodzące procesy społeczne, ekonomiczne oraz inwestycyjne nieustannie determinują ustawodawcę do

15 E. Szczygłowska, Sukcesja uprawnień i obowiązków administracyjnych, Warszawa 2009, s. 17 i przywołana tam literatura. Podobnie A. Matan, Następstwo (sukcesja) z mocy prawa $w$ materialnym prawie administracyjnym, „Casus” 2008, Nr 4, s. 19.

16 G. Łaszczyca, R. Sasiak, Łacczenie spółek kapitałowych a sukcesja praw i obowiązków ze sfery publicznoprawnej (wybrane zagadnienia), „Prawo Spółek" 1999, zeszyt 4, s. 2.

17 T. Woś, Moc wiążąca aktów administracyjnych w czasie, Warszawa 1978, s. 109.

18 E. Ochendowski, Prawo administracyjne, część ogólna, Toruń 2004, s. $40-41$.

19 Zob. również M. K. Ziemski, Sukcesja praw i obowiązków publicznoprawnych, „ZNSA” 2009, nr 1, s. 9. 
wprowadzania do porządku prawnego przepisów należących do kategorii norm zapewniających możliwość sukcesji decyzji administracyjnych. Potwierdzeniem tej tezy jest choćby art. 40 ustawy prawo budowlane, określający możliwość przeniesienia pozwolenia na budowę, czy art. 63 ust. 5 ustawy z 27 marca 2003 r. o planowaniu i zagospodarowaniu przestrzennym ${ }^{20}$, zapewniający możliwość przeniesienia decyzji o warunkach zabudowy i zagospodarowania terenu. Przykłady wspomnianych unormowań dotyczących substytucji adresata decyzji stwarzają szansę na zachowanie ciągłości realizacji zamierzeń inwestycyjnych oraz pozwalają na zaoszczędzenie czasu i środków niezbędnych do uzyskania określonej decyzji administracyjnej.

Jak słusznie zauważa E. Szczygłowska, lektura przepisów materialnego prawa administracyjnego daje podstawę do określenia wyjątków od zasady identyczności i stałości adresata decyzji administracyjnych. Zdaniem autorki, w szczególności odstępstwo to odnosi się do tzw. rzeczowych aktów administracyjnych, które przechodzą na każdoczesny podmiot dysponujący odpowiednim prawem do danej rzeczy. Chodzi oczywiście o rzecz, wobec której wydana została konkretna decyzja administracyjna, np. działka gruntu stanowiąca daną nieruchomość. Ewa Szczygłowska podkreśla, że trend do przenoszenia praw i obowiązków wraz z rzeczą pojawia się przede wszystkim w aktach prawnych odnoszących się do problematyki procesu inwestycyjnego oraz ochrony środowiska ${ }^{21}$. Jak zostało wspomniane wcześniej, pozwolenie wodnoprawne skutecznie łączy regulacje obu tych materii.

Dopuszczalna przez przepisy sukcesja praw i obowiązków wynikających z decyzji administracyjnej, nastąpić może w dwojaki sposób: z mocy samego prawa albo poprzez wydanie odrębnej decyzji administracyjnej2 ${ }^{22}$. Zmiana adresata decyzji jest

20 Ustawa o planowaniu i zagospodarowaniu przestrzennym z 27 marca 2003 r., tj. Dz. U. z 2012, poz. 647 ze zm.

21 E. Szczygłowska, op. cit., s. 18.

22 E. Skorczyńska, Sukcesja publicznoprawna $w$ procesie łączenia sie spółek na tle pojęcia następstwa prawnego w prawie administracyjnym, „Prawo Spółek" 2003, zeszyt 11, s. 15. 
wykluczona, jeśli miałaby nastąpić wyłącznie poprzez czynność cywilnoprawną a ustawodawca takiej możliwości nie przewidział w normie prawnej ${ }^{23}$. Jednakże w wielu sytuacjach, bez uprzedniego zaistnienia zdarzenia cywilnoprawnego transfer praw i obowiązków na nowy podmiot byłby niemożliwy ${ }^{24}$.

\section{WARUNKI PRZENOSZENIA POZWOLENIA WODNOPRAWNEGO NA GRUNCIE ART. 134 UST. 1 USTAWY PRAWO WODNE}

Przyjąć należy, że przeniesienie pozwolenia wodnoprawnego należy do tzw. sukcesji $\mathrm{w}$ ramach prawa materialnego. Ma to miejsce wówczas, gdy ,jeden adresat działań administracji przejmuje prawa i obowiązki o charakterze administracyjnym drugiego"25. Odrzucić należy poglądy dające możliwość dokonywania sukcesji praw i obowiązków jedynie z uwagi na rzeczowy charakter danej decyzji administracyjnej ${ }^{26}$. Niedopuszczalną jest również sytuacja zmiany adresata decyzji wyłącznie $\mathrm{w}$ oparciu o normę proceduralną zawartą $\mathrm{w}$ art. 155 kodeksu postępowania administracyjnego ${ }^{27}$.

W przypadku pozwolenia wodnoprawnego w artykule 134 ustawy prawo wodne odnaleźć możemy niebudzącą wątpliwości normę prawną zezwalającą (pod pewnymi warunkami) na przeniesienie takiego pozwolenia. W myśl tego przepisu ustawodawca wprowadził dwa tryby odnoszące się odpowiednio do

23 M. J. Nowak, Z. Olech, Regulacja sukcesji administracyjnoprawnej $w$ kodeksie spótek handlowych, „Przegląd Prawa Handlowego” 2008, Nr 1, s. 39.

24 M. Jaśkowska, A. Wróbel, Komentarz aktualizowany do art. 30 kodeksu postępowania administracyjnego, stan na dzień 20.07.2014 r., system informacji prawnej LEX.

25 M. Miemiec, Następstwo prawne $w$ prawie administracyjnym, „Przegląd Prawa i Administracji” 1990, tom XXVI, s. 27 i n., za: E. Szczygłowska, op. cit., s. 36.

26 E. Szczygłowska, op. cit., s. 265.

27 Orzeczenie WSA w Białymstoku z dnia 10 kwietnia 2014 r., sygn. II SA/Bk 1169/13, http://orzeczenia.nsa.gov.pl/doc/72E93FE196. 
dwóch rodzajów pozwoleń wodnoprawnych - dotyczących eksploatacji instalacji i takich, które eksploatacji instalacji nie dotyczą. W przypadku pozwolenia wodnoprawnego nie dotyczącego eksploatacji instalacji następca prawny zakładu, który uzyskał pozwolenie wodnoprawne przejmuje prawa i obowiązki z mocy samego prawa. W drugiej sytuacji, która odnosi się do pozwolenia wodnoprawnego dotyczącego eksploatacji instalacji, przeniesienie decyzji administracyjnej następuje w oparciu o przepisy ustawy p.o.ś. W myśl art. 134 ust. 3 ustawy prawo wodne odpowiednie przepisy ustawy p.o.ś. mają zastosowanie również do przejęcia praw i obowiązków, wynikających z pozwolenia na wprowadzanie do urządzeń kanalizacyjnych, będących własnością innych podmiotów, ścieków przemysłowych zawierających substancje szczególnie szkodliwe dla środowiska.

W celu zrozumienia instytucji przeniesienia pozwolenia wodnoprawnego na gruncie art. 134 ust. 1 ustawy prawo wodne należy poddać analizie użyte $\mathrm{w}$ omawianym przepisie pojęcia. Termin „zakład” w rozumieniu ustawy prawo wodne został zdefiniowany jako podmiot korzystający z wód w ramach korzystania szczególnego, wykonujący urządzenia wodne lub wykonujący inne działania wymagające pozwolenia wodnoprawnego. Ustawodawca nie przesądził zatem o formie, w ramach której dany zakład miałby podejmować wyżej określone działania. Wobec tego może to być każdy podmiot prawa podejmujący określoną przez ustawę aktywność ${ }^{28}$. W tym miejscu należy podkreślić, że zarówno ustawa prawo wodne, jak i ustawa p.o.ś. zawiera własne, odmienne uregulowania dotyczące znaczenia pojęcia „zakładu”, odsyłając do definicji legalnych zawartych odpowiednio: w art. 9 ust. 1 pkt 25 (opisany wyżej) oraz art. 3 ust. 1 pkt 48. Pojęć tych nie należy ze sobą utożsamiać29.

Kolejnym terminem wymagającym wyjaśnienia jest pojęcie „następcy prawnego”. Znaczenia zawartego w tekście sformu-

28 Pośrednio potwierdza to orzeczenie WSA w Poznaniu z dnia 11 lipca 2013 r., sygn. II SA/Po 1112/12, Centralna Baza Orzeczeń Sądów Administracyjnych, http://orzeczenia.nsa.gov.pl/doc/DAC290E707.

29 B. Rakoczy, Komentarz do art. 9 ustawy - Prawo wodne, teza 4, system informacji prawnej LEX 2013. 
łowania szukać należy głównie na gruncie nauki prawa cywilnego. Następstwem prawnym będzie zatem pochodne nabycie (sukcesja) prawa podmiotowego innej osoby, którym w tradycyjnej nauce prawa nazywa się wstąpienie w sferę stosunków prawnych swego poprzednika. Jest to zatem nic innego, jak sukcesja praw i obowiązków jednego podmiotu przez drugi ${ }^{30}$.

Istnieją dwa rodzaje nabycia pochodnego: sukcesja uniwersalna (succesio universalis), określana mianem sukcesji pod tytułem ogólnym, oraz druga, sukcesja syngularna (succesio singularis) - pod tytułem szczególnym ${ }^{31}$. Rozróżnienie takie ma na celu określenie sposobu przeniesienia danego prawa lub praw.

$\mathrm{Na}$ gruncie nauk cywilistycznych, z sukcesją syngularną mamy do czynienia w sytuacji, gdy następca prawny przejmuje tylko jedno, indywidualnie oznaczone prawo podmiotowe swego poprzednika w wyniku zajścia jednego zdarzenia prawnego. Sukcesja uniwersalna ma miejsce natomiast wtedy, gdy cały majątek bądź jego wyodrębniona część przechodzą na następcę na podstawie jednego zdarzenia prawnego ${ }^{32}$. Należy podkreślić, że zgodnie $\mathrm{z}$ zasadą nemo in alium plus iuris transferre potest, quam ipse habet następca prawny nie może nabyć więcej praw niż posiadał jego poprzednik ${ }^{33}$.

W tym miejscu należałoby wspomnieć o fakcie istnienia istotnych różnic między następstwem prawnym prawa cywilnego a tym ujmowanym przez prawo administracyjne. Jak słusznie podkreśla E. Szczygłowska, różnice takie pojawiają się choćby ze względu na odmienność stosunku cywilnoprawnego od stosunku administracyjnego ${ }^{34}$. Stąd też wydaje się być trafną definicja następstwa administracyjnoprawnego, gdzie jeden z podmiotów (następca prawny), określany jako zewnętrzny

30 A. Koper, Następstwo prawne, Encyklopedia Gazety Prawnej. http://www.gazetaprawna.pl/encyklopedia/prawo/hasla/334536, nastep stwo_prawne.html.

31 Ibidem.

32 E Szczygłowska, op. cit., s. 27.

33 S. Grzybowski, Prawo cywilne. Zarys prawa rzeczowego, Warszawa 1976, s. 35; J. Ignatowicz, Prawo rzeczowe, Warszawa 1998, s. 13. Obie pozycje za: E. Szczygłowska, op. cit., s. 27 i 28.

34 Zob. szerzej: E. Szczygłowska, op. cit., s. 32 i n. 
względem administracji, przejmuje prawa i obowiązki o charakterze administracyjnoprawnym drugiego podmiotu, w wyniku czego powstaje nowy stosunek administracyjnoprawny ${ }^{35}$. Definicja ta, zaproponowana przez E. Szczygłowską, pozwala również na jasne rozróżnienie instytucji zastępstwa $\mathrm{w}$ wykonywaniu praw czy obowiązków przez podmiot, na który uprawnienia i obowiązki te de facto nie przechodzą, a który jedynie wykonuje je, w ramach upoważnienia drugiego podmiotu. Nie staje się on następcą prawnym (sukcesorem uprawnień i obowiązków administracyjnoprawnych), lecz wyłącznie zastępcą przy wykonywaniu określonych działań, ponieważ nowy stosunek administracyjnoprawny nie zostaje nawiązany ${ }^{36}$.

Dokonując analizy art. 134 ust. 1 ustawy prawo wodne, można wyobrazić sobie sytuację, w której następca prawny zakładu wstępuje w prawa i obowiązki poprzednika w wyniku sukcesji uniwersalnej (np. w wyniku dziedziczenia), jak i syngularnej (np. poprzez sprzedaż nieruchomości, na której zlokalizowane jest dane urządzenie wodne). Wątpliwości w stosunku do konkretnego podziału praw i obowiązków wynikających z pozwolenia wodnoprawnego pojawiły się w sytuacji podziału zakładu. Rozwiązanie zaproponowane przez Wojewódzki Sąd Administracyjny w Poznaniu w wyroku z dnia 12 czerwca 2014 r. $^{37}$ przewidywało, że „przy podziałach zakładu prawa i obowiązki wynikające z pozwolenia wodnoprawnego przechodziły na ten podmiot, który nabył prawo do urządzeń, do których odnosiło się pozwolenie". Nie sposób nie zgodzić się z tym stwierdzeniem, bowiem podmiot, który w drodze sukcesji nabywa tytuł prawny do urządzenia wodnego, staje się również następcą prawnym pozwolenia wydanego na swego poprzednika.

35 E. Szczygłowska, op. cit., s. 42.

36 Ibidem.

37 Wyrok WSA w Poznaniu z dnia 12 czerwca 2014 r., sygn. IV SA/Po 1257/13, http://orzeczenia.nsa.gov.pl/doc/8E20A0B302. 


\section{WARUNKI PRZENOSZENIA POZWOLENIA WODNOPRAWNEGO NA GRUNCIE USTAWY P.O.Ś. W ZWIĄZKU Z ART. 134 UST. 2 USTAWY PRAWO WODNE}

Zgodnie z art. 134 ust. 2 ustawy prawo wodne, jeżeli pozwolenie wodnoprawne dotyczy eksploatacji instalacji, przejęcie praw i obowiązków wynikających z pozwolenia następuje na zasadach określonych w ustawie p.o.ś.

Przed uchwaleniem ustawy nowelizującej problematykę tę regulowały głównie art. 190 i 191 ustawy p.o.ś., które w wyniku zmian legislacyjnych zostały uchylone w całości. W tym miejscu, w celu zachowania ciągłości wywodu myślowego oraz zobrazowania charakteru zmian pokrótce przedstawić należy kształt dotychczas obowiązujących w tym zakresie regulacji.

Zgodnie z ustępem 1 nieobowiązującego już art. 190 ustawy p.o.ś. zainteresowany nabyciem tytułu prawnego do całej instalacji mógł złożyć wniosek o przeniesienie na niego praw i obowiązków wynikających z pozwoleń dotyczących tej instalacji. Ustęp 3 tego artykułu stanowił natomiast, że przeniesienie lub odmowa przeniesienia praw i obowiązków następowała w drodze wydania nowej decyzji administracyjnej.

W wyniku wprowadzenia przez ustawę nowelizującą zmian dotyczących procedury przenoszenia pozwoleń wodnoprawnych, art. 134 ust. 2 ustawy prawo wodne nie odsyła już do wspomnianych art. 190 i 191 ustawy p.o.ś., lecz do nowo wprowadzonych regulacji.

Artykuł 181 ust. 3 znowelizowanej ustawy p.o.ś. wskazuje z kolei, że do pozwoleń wodnoprawnych na wprowadzanie ścieków do wód lub do ziemi stosuje się odpowiednio przepisy art. 187, art. 188 ust. 3 pkt 2 i ust. 4, art. 189, art. 193 ust. 2 i art. 198 tej ustawy.

Najważniejszą zmianą, która zaszła na gruncie uchwalenia ustawy nowelizującej jest wprowadzenie nowej treści art. 189: „1. Podmiot, który staje się prowadzącym instalację lub jej oznaczoną część, przejmuje prawa i obowiązki wynikające z pozwoleń dotyczących tej instalacji lub jej oznaczonej części. 
2. Podmiot, o którym mowa w ust. 1, występuje niezwłocznie $\mathrm{z}$ wnioskiem o zmianę pozwoleń w zakresie oznaczenia prowadzącego instalację".

Należy podkreślić aktualność definicji pojęcia „instalacja”, zawartej w art. 3 pkt 6 ustawy p.o.ś., rozumianej jako „stacjonarne urządzenie techniczne, zespół stacjonarnych urządzeń technicznych powiązanych technologicznie, do których tytułem prawnym dysponuje ten sam podmiot i położonych na terenie jednego zakładu, budowle niebędące urządzeniami technicznymi ani ich zespołami, których eksploatacja może spowodować emisję". Nie budzi wątpliwości, że instalacją w rozumieniu ustawy p.o.ś. na gruncie prawa wodnego będzie urządzenie wodne ${ }^{38}$.

W obecnym kształcie przepis wprowadza istotną zmianę $\mathrm{w}$ procedurze przenoszenia pozwolenia wodnoprawnego, dotyczącego eksploatacji instalacji, wprowadzając automatyzm takiej sukcesji. Oznacza to, że zaistnienie zdarzeń opisanych $\mathrm{w}$ hipotezie analizowanej normy prawnej powoduje zmianę po stronie adresata decyzji bez udziału organu administracji publicznej. W przeciwieństwie do dotychczas obowiązującego stanu prawnego nie jest już konieczne uzyskanie odrębnej decyzji przenoszącej pozwolenie wodnoprawne na inny podmiot. Jedynym wymogiem stawianym wobec nowego sukcesora uprawnień i obowiązków jest wystąpienie bez zbędnej zwłoki z wnioskiem o zmianę oznaczenia nowego adresata decyzji. Należy w tym miejscu stwierdzić, że dyspozycja zawarta w ust. 2 omawianego przepisu stanowi obowiązek zainicjowania postępowania jedynie „subsydiarnego” wobec zdarzenia, które już zaistniało, wywołując skutki prawne. Orzeczenie organu w tym przedmiocie będzie miało zatem charakter wyłącznie deklaratoryjny.

Pośredni wpływ na wprowadzenie zmian dotyczących procedury przenoszenia praw i obowiązków z pozwoleń wodnoprawnych ma implementacja dyrektywy Parlamentu Europejskiego i Rady z dnia 24 listopada 2010 r. w sprawie emisji

38 J. Sommer, Komentarz do art. 122, [w:] J. Rotko (red.), Prawo wodne. Komentarz, Wrocław 2002, s. 304-316. 
przemysłowych ${ }^{39}$. Warto nadmienić, że zastąpiła ona siedem dotychczas obowiązujących dyrektyw.

Jednym z jej założeń jest uproszczenie stanu legislacyjnego oraz modyfikacja systemu wydawania i przenoszenia pozwoleń wodnoprawnych ${ }^{40}$. Faktycznie, zmiany, które wprowadza ustawa nowelizująca znacząco upraszczają dotychczasową żmudną i czasochłonną procedurę przenoszenia decyzji administracyjnej jaką jest pozwolenie wodnoprawne. Wcześniejsze regulacje wymagały, aby zainteresowany przeniesieniem takiego pozwolenia najpierw złożył wniosek o jego przeniesienie oraz uzyskanie decyzji administracyjnej, a następnie dopiero uzyskał tytuł prawny do całej instalacji.

W tym miejscu należy podkreślić absolutnie kuriozalny charakter poprzedniej regulacji. Podmiot, który nabył tytuł prawny do instalacji, nie mógł już uzyskać przeniesienia pozwolenia na jej eksploatację, podczas gdy podmiot jedynie zainteresowany nabyciem takiego tytułu mógł uzyskać decyzję przenoszącą. Nabycie tytułu prawnego przed przeniesieniem pozwolenia wodnoprawnego do danej instalacji skutkowało wygaśnięciem tego pozwolenia z uwagi na jego bezprzedmiotowość. Mogło wówczas dojść do dwojakiego rodzaju sytuacji. Pierwsza, gdy zainteresowane eksploatacją instalacji podmioty nabyły prawo do danej instalacji, lecz nie rozpoczęły jeszcze jej eksploatacji. Skutkowało to wyłącznie koniecznością wystąpienia z wnioskiem o wydanie nowego pozwolenia i oczekiwaniem na decyzję o jego udzielenie. W rezultacie zainteresowany inwestor musiał oczekiwać na zakończenie często długotrwałej procedury związanej z uzyskaniem nowego pozwolenia.

Druga sytuacja, zdecydowanie bardziej dolegliwa, następowała wówczas gdy ten, który dysponował tytułem prawnym do instalacji, dokonywał jej eksploatacji, nie będąc do

39 Dyrektywa Parlamentu Europejskiego i Rady 2010/75/UE z dnia 24 listopada 2010 r. w sprawie emisji przemysłowych (zintegrowane zapobieganie zanieczyszczeniom i ich kontrola), Dz. Urz. UE L 334 z 17.12.2010, s. 17 ze zm., dalej: dyrektywa IED.

40 Uzasadnienie do rządowego projektu ustawy o zmianie ustawy - Prawo ochrony środowiska oraz niektórych innych ustaw, Nr 2162, s. 1, http://www. sejm.gov.pl/Sejm7.nsf/druk.xsp?nr=2162. 
tego uprawnionym. W rezultacie powodowało to aktualizację sankcji natury administracyjnoprawnej (w tym również ponoszenie podwyższonych opłat za korzystanie ze środowiska bez uprawnień ${ }^{41}$ ), a co więcej, powstanie odpowiedzialności karnej na podstawie (obowiązującego w niezmienionej do dziś treści) art. 351 ustawy p.o.ś. ${ }^{42}$.

Obecny stan prawny powoduje, że nabycie tytułu prawnego do całości lub części instalacji aktualizuje automatyczne przejście pozwolenia wodnoprawnego na ten podmiot, bez konieczności wcześniejszego przeniesienia pozwolenia odrębną decyzją. Nowa procedura rozwiązuje problem, z którym borykali się przedsiębiorcy, którym zależało na szybkiej i sprawnej realizacji swojej inwestycji w celu eksploatacji nowo nabytej instalacji. Nie muszą oni bowiem oczekiwać na przeniesienie pozwolenia, aby móc rozpoczynać procesy związane z nabyciem przez nich tytułu prawnego do danej instalacji. Co więcej, na gruncie obowiązywania poprzednich przepisów występowały sytuacje, kiedy zainteresowane eksploatacją instalacji podmioty, nie zdając sobie sprawy z istnienia takich przepisów, najpierw nabywały prawa do danej instalacji, co skutkowało koniecznością wystąpienia z wnioskiem o wydanie nowego pozwolenia i oczekiwanie na decyzję o jego udzielenie.

Wprowadzone zmiany nie usuwają jednak wszystkich wątpliwości, a nawet stwarzają kolejne problemy interpretacyjne. W celu ich przedstawienia konieczną staje się analiza pojęć użytych w art. 189 ustawy p.o.ś.

41 Zob. Orzeczenie WSA w Warszawie z dnia 22 maja 2013 r., VIII SA/Wa 102/13, http://orzeczenia.nsa.gov.pl/doc/B99D8813F9 i Orzeczenie WSA w Warszawie z dnia 5 czerwca 2013 r., VIII SA/Wa 96/13, http://orzeczenia.nsa.gov.pl/doc/213150C77D.

42 Przepis ten konstruuje ogólną zasadę, zgodnie z którą podmiot, który eksploatuje instalację bez wymagania pozwolenia lub z naruszeniem jego warunków, podlega karze aresztu albo ograniczenia wolności, albo grzywny. Należy podkreślić, że do wypełnienia znamion czynu zabronionego, o którym mowa w tym przepisie, wystarczy już sam brak stosownego pozwolenia, a także eksploatacja instalacji wprawdzie z wymaganym pozwoleniem, jednak z naruszeniem przesłanek, które ona określa. Zob. B. Rakoczy, [w:] Z. Bukowski, E. K. Czech, K. Karpus, B. Rakoczy, Prawo ochrony środowiska. Komentarz, Warszawa 2013, s. 635 i 636. 
Zgodnie z definicją ustawową zawartą w art. 3 pkt 31 ustawy p.o.ś. „prowadzącym instalację” jest podmiot uprawniony na podstawie określonego tytułu prawnego do władania instalacją w celu jej eksploatacji zgodnie z wymaganiami ochrony środowiska, na zasadach wskazanych w ustawie. Ponadto, art. 183a ustawy p.o.ś. rozszerza pojęcie prowadzącego o podmiot uprawniony, na podstawie określonego tytułu prawnego, do władania określoną częścią instalacji. Tytułem prawnym z kolei jest prawo własności, użytkowanie wieczyste, trwały zarząd, ograniczone prawo rzeczowe albo stosunek zobowiązaniowy (art. 3 pkt 41 ustawy p.o.ś.). Należy w tym miejscu zwrócić szczególną uwagę na znaczenie pojęcia „władanie”, które stanowi element posiadania (gdy posiadacz włada z psychicznym nastawieniem, że włada rzeczą dla siebie) albo dzierżenia (czyli władanie rzeczą za kogoś innego) ${ }^{43}$.

Posiadanie zaś to stan faktyczny, którym nieodłącznym elementem jest fizyczne władanie rzeczą (corpus possesionis). Stosownie zaś do treści art. 3 pkt 3 ustawy p.o.ś. „eksploatacja instalacji lub urządzenia" to użytkowanie instalacji lub urządzenia oraz utrzymywanie ich w sprawności. Naturalną konsekwencją tych zapisów jest konieczność, by taka instalacja istniała, aby w ogóle mógł zaistnieć stan władania, a co więcej eksploatowania instalacji. Niemożliwym staje się zatem już samo posiadanie nieistniejącej instalacji, a co z tego wynika, władanie nią, a w konsekwencji prowadzenie jej w celu eksploatacji. Uzasadniony wykładnią językową pozostaje zatem wniosek, że pozwolenie wodnoprawne nie może zmienić adresata w oparciu o art. 189 ustawy p.o.ś. w sytuacji, gdy instalacja nie istnieje. Jak zostało bowiem wyjaśnione, bez jej istnienia żaden podmiot nie może stać się jej prowadzącym. Przepis ten zwęził krąg możliwych sukcesorów praw i obowiązków wynikających z pozwolenia wyłącznie do podmiotów mających status prowadzących instalację.

Na podstawie zaś art. 191a ustawy p.o.ś. w związku z art. 184 ust. 1 ustawy p.o.ś. pozwolenie wodnoprawne może być

43 http://www.gazetaprawna.pl/encyklopedia/prawo/hasla/336118, posiadanie.html. 
wydane również na wniosek podmiotu podejmującego realizację nowej instalacji. Oznacza to, że pozwolenie takie może być wydane nie tylko podmiotowi, który posiada status prowadzącego instalację, ale także temu, kto podejmuje realizację nowej inwestycji ${ }^{44}$. Rodzi to poważne problemy w sytuacji pojawienia się woli przeniesienia praw i obowiązków z pozwolenia wodnoprawnego wydanego na podstawie art. 191a ustawy p.o.ś. w sytuacji, gdy dana instalacja lub jej określona część jeszcze nie istnieje. Przepis 189 ustawy p.o.ś. stanowi bowiem o automatycznej sukcesji pozwolenia, określając sukcesora jako „prowadzącego instalację”, zaś podmiot określony w art. 191a ustawy p.o.ś. takim prowadzącym nie jest. Można zatem skonkludować, że aby mogła być mowa o przeniesieniu pozwolenia w trybie art. 189 ustawy p.o.ś., podmiot uzyskanego uprzednio na podstawie art. 191a pozwolenia musi wcześniej stać się prowadzącym daną instalację. Do takich wniosków należy dojść, kierując się wykładnią logiczno-językową. Inne ustalenia interpretacyjne stanowiłby przejaw wykładni contra legem. Niemożliwość sukcesji pozwolenia wydanego na podstawie art. 191a ustawy p.o.ś. kłóci się z celem ustawodawcy, jakim było ułatwienie i usprawnienie procesów inwestycyjnych. Można bowiem wyobrazić sobie sytuację, w której tzw. inwestor zastępczy uzyskuje pozwolenie na podstawie art. 191a, a następnie zamierza przekazać realizację inwestycji innemu podmiotowi. $\mathrm{W}$ praktyce ma to miejsce, gdy głównym zadaniem inwestora zastępczego jest przygotowanie dokumentacji, uzyskanie niezbędnych decyzji administracyjnych (w tym pozwolenia wodnoprawnego) oraz przeniesienie ich na inwestora zasadniczego. W celu zachowania ważności uzyskanego pozwolenia wodnoprawnego inwestor zastępczy musiałby zrealizować instalację. W aktualnym stanie prawnym cele działań podejmowanych przez takie podmioty stają się zatem znacznie utrudnione, a zamysł jaki przyświecał ustawodawcy nie zostaje w pełni zrealizowany. W związku z powyższym należałoby zasugerować wprowadzenie do art. 189 ustawy p.o.ś. uregulowań zapewniających

44 Orzeczenie WSA w Gdańsku z dnia 12 marca 2014 r., II SA/Gd 38/14, http://orzeczenia.nsa.gov.pl/doc/730383ABEB. 
skuteczną możliwość przeniesienia pozwolenia wodnoprawnego wydanego w oparciu o art. 191a tej ustawy. Skutek taki można osiągnąć poprzez wprowadzenie dodatkowego przepisu o przykładowym brzmieniu: „do pozwolenia wodnoprawnego wydanego podmiotowi określonemu w art. 191a stosuje się odpowiednio przepisy art. 189".

W praktyce urzędniczej niejednokrotnie w jednej decyzji administracyjnej organ zezwala zarówno na wybudowanie urządzeń wodnych oraz na ich eksploatację. Jeśli jednym z podmiotów jest inwestor zastępczy, jasnym jest, że nie będzie on zainteresowany wybudowaniem instalacji samemu, lecz wyłącznie przekazaniem pozwoleń wodnoprawnych głównemu inwestorowi. Powstaje wówczas problem ewentualnej możliwości podziału jednej decyzji na pozwolenie na budowę urządzenia wodnego i pozwolenie na jego eksploatację. Jak zostało bowiem wcześniej omówione, przeniesienie pozwolenia na eksploatację instalacji może nastąpić wyłącznie po jej powstaniu. NSA przychylił się w swym orzeczeniu do stwierdzenia zezwalającego (w konkretnych sprawach i okolicznościach) na odrębny byt prawny wielu rozstrzygnięć z jednej decyzji w przypadku, „gdy sprawa może być załatwiona tylko w pewnym zakresie, albo gdy decyzja kończąca zawiera elementy mogące samodzielnie funkcjonować w obrocie prawnym"45. Najkorzystniejszym jednak rozwiązaniem, które nie powodowałoby żadnych problemów interpretacyjnych związanych z podziałami wydanych decyzji administracyjnych, byłoby uzyskanie dwóch odrębnych decyzji (pozwolenie na wybudowanie urządzenia wodnego i osobno drugiego, na jego eksploatację). Wówczas, na podstawie obecnie obowiązujących przepisów pierwsze z tych pozwoleń przechodziłoby na następcę prawnego zakładu zgodnie $\mathrm{z}$ art. 134 ust. 1 ustawy prawo wodne. Druga decyzja natomiast wygasałaby z powodu niedoskonałości przepisu 189 ust. 1 ustawy p.o.ś., którego dotyka problem opisany w powyższej części opracowania. Wygaśnięcie takie nastąpiłoby wówczas na podstawie art. 193 ust. 1 pkt 2 ustawy p.o.ś., zgodnie z którym pozwole-

45 Orzeczenie NSA z dnia 18 października 2012 r., sygn. I OSK 281/12, niepublikowany, http://orzeczenia.nsa.gov.pl/doc/A0F6D0921D. 
nie wygasa, jeżeli podmiot przestał być prowadzącym instalację lub z innych powodów pozwolenie stało się bezprzedmiotowe. Bezprzedmiotowość ta miałaby miejsce, gdyż podmiot, o którym mowa w art. 191a ustawy p.o.ś., przestałby realizować hipotezę zawartą $\mathrm{w}$ tej normie stanowiącą o „byciu podmiotem podejmującym realizację nowej instalacji". Nie mógłby on być zatem nadal podmiotem praw i obowiązków wynikających z pozwolenia wydanego na podstawie tego przepisu, a wspomniana ułomność art. 189 ustawy p.o.ś. nie pozwala na przejście problematycznego pozwolenia na inwestora, który nie jest jeszcze „prowadzącym instalację”. Konsekwentnie, jeśli do stanu prawnego wprowadziłby ustawodawca dodatkowy zapis zaprezentowany powyżej przez autorów niniejszego artykułu, problem przeniesienia decyzji udzielającej dwóch pozwoleń jednocześnie przestałby istnieć.

Nowe przepisy regulujące przenoszenie pozwoleń wodnoprawnych mają wpływ nie tylko na inwestorów, dotykają również bezpośrednio kompetencji organów administracyjnych. $\mathrm{Na}$ gruncie bowiem nowego stanu prawnego przeniesienie pozwolenia następuje bez konieczności uzyskania zgody organu administracji publicznej. Został on pozbawiony możliwości wcześniejszej weryfikacji rękojmi prawidłowej eksploatacji instalacji wymaganej od sukcesora pozwolenia. Stwarza to sytuacje, w których organ administracji nie będzie mógł zawczasu zapobiegać nadużyciom (ewentualnym szkodom w środowisku).

$\mathrm{Na}$ wprowadzenie zmian omawianych regulacji wpływ miała konieczność implementacji wspomnianej we wcześniejszej części opracowania dyrektywy IED. Ustawodawca wprowadził nową regulację przepisu 183b ustawy p.o.ś., która wynikała bezpośrednio z art. 4 dyrektywy IED, stanowiącego o możliwości kształtowania sytuacji, gdy określone części instalacji są prowadzone przez kilku operatorów. Oczywistym jest, że w takim przypadku prawa i obowiązki takich osób powinny być jasno sprecyzowane $^{46}$. 
Wprowadzony przez ustawę nowelizującą art. 183b ust. 1 ustawy p.o.ś. stanowi, że o ile osoby prowadzące oznaczone części instalacji wystąpią z odpowiednim wnioskiem, części tej instalacji mogą zostać objęte jednym pozwoleniem. Jednocześnie uprawnieni z ust. 1 muszą, zgodnie z ust. 2 tego przepisu, wskazać jednego z nich jako głównego prowadzącego lub szczegółowo określić zakres odpowiedzialności poszczególnych podmiotów za eksploatację instalacji zgodnie z normami ustawy p.o.ś.

Po pierwsze wskazać należy, iż przepis ten dotyczy procedury wydania nowego pozwolenia. Pomimo istnienia regulacji stanowiącej o odpowiednim stosowaniu do procedury zmiany pozwoleń norm dotyczących procesu jej wydawania (art. 192 ustawy p.o.ś.), nie rozwiązuje on problemów, jakie mogą zaistnieć w przypadkach przenoszenia pozwoleń na gruncie art. 189 ustawy p.o.ś.

Niestety, przepis z art. 183b ustawy p.o.ś. wskazuje jedynie rozwiązanie w sytuacji, gdy instalacja prowadzona jest przez różne podmioty, które mają tytuł prawny do władania określonymi częściami instalacji. Dodatkowo muszą one wykazywać wolę objęcia eksploatacji takiej instalacji jednym pozwoleniem. Nie usuwa on jednak szeregu wątpliwości, jakie pojawić się mogą na tle regulacji art. 189 ustawy p.o.ś. w związku z możliwością zaistnienia sytuacji wielości sukcesorów pozwolenia. Z uwagi na charakter oraz ograniczone ramy niniejszego opracowania zasygnalizowane zostaną tylko niektóre $\mathrm{z}$ wybranych problematycznych zagadnień.

Pierwsza sytuacja wymagająca analizy może mieć miejsce w przypadku sukcesji uniwersalnej (np. poprzez dziedziczenie) całości majątku, w tym instalacji oraz pozwolenia na jej eksploatację przez wiele podmiotów (prowadzących). Można bowiem bez żadnych przeszkód wyobrazić sobie sytuację, w której poprzez dziedziczenie, prawa i obowiązki przechodzą na spadkobierców w równych częściach. Jako sukcesorzy z art. 189 ustawy p.o.ś. każdy z tych podmiotów staje się prowadzącym instalację (w przypadku, gdy instalacja istnieje oraz każdy z nich spełnia przesłanki definicji legalnej prowadzącego) w częściach równych. Jeśli wyrażają oni wolę podziału tej instalacji na części 
(a instalację tę można bez przeszkód $\mathrm{w}$ ten sposób podzielić bez utraty jej właściwości), każdy z nich staje się prowadzącym swoją wyodrębnioną część danej instalacji, korzystając w odpowiednim zakresie z przeniesionych praw i obowiązków, przypisanych do danej części instalacji. Jeżeli jednak wyrażą oni wolę wskazania, który z podmiotów będzie głównym prowadzącym, lub zechcą określić szczegółowo zakres odpowiedzialności poszczególnych podmiotów, mogą wówczas złożyć wniosek o zmianę pozwolenia w oparciu o art. 183b ust. 2 ustawy p.o.ś. w związku z art. 192 ustawy p.o.ś.

Można sobie również wyobrazić sytuację, w której instalacja i pozwolenie z nią związane nie mogą być uczynione przedmiotem podziału (ze względu na jej właściwości) lub też gdy podmioty będące sukcesorami tej instalacji nie wyrażają woli jej podziału (nawet, gdy jest on możliwy nie dokonują go i stają się, przykładowo, współwłaścicielami w częściach równych). W tej sytuacji należałoby zgodzić się założeniem, że wszyscy sukcesorzy stają się prowadzącym całą instalację niepodzielnie, natomiast prawa i obowiązki spoczywają na każdym z tych podmiotów $\mathrm{w}$ takim samym zakresie ${ }^{47}$. Założenie takie prowadzi do wniosku, że podmioty te powinny odpowiadać na zasadach odpowiedzialności solidarnej. Brakuje jednak wyraźnego wskazania na taką odpowiedzialność w odpowiednim przepisie ${ }^{48}$. W przypadku niewywiązywania się z obowiązków ciążących na danych prowadzących należy uwzględnić przepisy rozdziału 3 działu IV tytułu III ustawy p.o.ś.

Omawiane problemy mogą również pojawić się w podobnym kształcie na gruncie art. 134 ust. 1 ustawy prawo wodne. Wynika to z podobieństwa omawianych regulacji dotyczących przenoszenia pozwoleń wodnoprawnych.

47 A. Skóra, Koncepcja wielopodmiotowych stosunków administracyjnoprawnych, [w:], J. Zimmermann (red.), Koncepcja systemu prawa administracyjnego, Warszawa 2007, s. 265.

48 Por. np. art. 3 ust. 4 ustawy z dnia 12 stycznia 1991 r. o podatkach i opłatach lokalnych, tj. Dz. U. 2014, nr 849 ze zm. 


\section{PODSUMOWANIE}

Jak zostało wykazane, problematyka dotycząca pozwolenia wodnoprawnego stanowi nieodłączny element regulacji dotyczących zagadnień ochrony środowiska i gospodarowania wodami. Wprowadzone przez ustawodawcę zmiany bez wątpienia upraszczają procedurę transferu pozwoleń wodnoprawnych, eliminując z niej udział organów administracji publicznej. Oceny dokonanych modyfikacji należy jednak dokonywać nie tylko ze względu na ułatwienie obrotu gospodarczego, lecz również z uwagi na możliwe skutki wyłączenia działań kontrolnych organów w przedmiocie sukcesji pozwoleń. Dodatkowo, ustawodawca, nie regulując $w$ pełni kwestii zagadnień przenoszenia pozwoleń wodnoprawnych dotyczących w szczególności aspektu wielopodmiotowości sukcesorów, pozostawił wiele wątpliwości interpretacyjnych.

\section{BIBLIOGRAFIA}

Czech E. K., Rola pozwolenia na wprowadzenie gazów lub pyłów do powietrza $w$ działaniach administracji publicznej, [w:] E. K. Czech (red.), Uwarunkowania ochrony środowiska. Aspekty krajowe, unijne, międzynarodowe, Warszawa 2006.

Grzybowski S., Prawo cywilne. Zarys prawa rzeczowego, Warszawa 1976.

Ignatowicz J., Prawo rzeczowe, Warszawa 1998.

Jaśkowska M., Wróbel A., Komentarz aktualizowany do art. 30 kodeksu postępowania administracyjnego, stan na dzień 20.07.2014 r., system informacji prawnej LEX.

Kijowski D. R., Pozwolenia w administracji publicznej, Białystok 2000. Kundera J., Szmyt W., Leksykon polityki regionalnej Unii Europejskiej, Kraków 2008.

Łaszczyca G., Sasiak R., Łacczenie spółek kapitałowych a sukcesja praw i obowiązków ze sfery publicznoprawnej (wybrane zagadnienia), „Prawo Spółek” 1999, zeszyt 4. 
Matan A., Następstwo (sukcesja) z mocy prawa $w$ materialnym prawie administracyjnym, „Casus” 2008, nr 4.

Miemiec M., Następstwo prawne w prawie administracyjnym, „Przegląd Prawa i Administracji" 1990, tom XXVI.

Nowak M. J., Olech Z., Regulacja sukcesji administracyjnoprawnej $w$ kodeksie spółek handlowych, „Przegląd Prawa Handlowego” 2008, Nr 1.

Ochendowski E., Prawo administracyjne, część ogólna, Torun 2004.

Radecki W., Ochrona środowiska. Problemy społeczne ekonomiczne i prawne, Warszawa 2001.

Bukowski Z., Czech E. K., Karpus K., Rakoczy B., Prawo ochrony środowiska. Komentarz, Warszawa 2013.

Rakoczy B., Komentarz do art. 9 ustawy - Prawo wodne, teza 4, system informacji prawnej LEX 2013.

Skorczyńska E., Sukcesja publicznoprawna w procesie łączenia się spótek na tle pojęcia następstwa prawnego $w$ prawie administracyjnym, „Prawo Spółek” 2003, zeszyt 11.

Skóra A., Koncepcja wielopodmiotowych stosunków administracyjnoprawnych, [w:] J. Zimmermann (red.), Koncepcja systemu prawa administracyjnego, Warszawa 2007.

Sommer J., Komentarz do art. 122, [w:] J. Rotko (red.), Prawo wodne. Komentarz, Wrocław 2002.

Szczygłowska E., Sukcesja uprawnień i obowiązków administracyjnych, Warszawa 2009.

Woś T., Moc wiążaca aktów administracyjnych $w$ czasie, Warszawa 1978.

Ziemski M. K., Sukcesja praw i obowiązków publicznoprawnych, „ZNSA” 2009, nr 1.

Kontakt e-mail:

ciesielska.aleksandra@gmail.com 